\title{
Growth Characteristics and Root Calcium Absorption of Watermelon Seedlings as Influenced by the Fungicides Captan and Thiram
}

\author{
Aimin Liu ${ }^{1}$, Joyce G. Latimer ${ }^{2}$, and Robert E. Wilkinson ${ }^{3}$ \\ Georgia Experiment Station, The University of Georgia, Griffin, GA 30223-1797
}

\begin{abstract}
Additional index words. acidic soil tolerance, Citrullus lanatus, ion uptake
Abstract. The influence of two fungicides—captan and thiram-on growth and ${ }^{45} \mathrm{Ca}$ absorption by roots of 'Starbrite' watermelon [Citrullus lanatus (Thunb.) Matsum. and Nakai] seedlings was investigated. Unilateral application of Ca $\mathrm{a}^{+2}$ and $\mathrm{Al}$ in agar induced curvature in roots from untreated and pretreated seeds. In untreated seeds, $\mathrm{PCMBS}$ inhibited $\mathrm{Ca}^{+2}-$ and $\mathrm{Al}$-induced root curvature by $82 \%$ and $92 \%$, respectively. In commercially pretreated seeds (captan + thiram), PCMBS inhibited $\mathrm{Ca}^{+2}$ - but not Al-induced root curvature. Captan or thiram also inhibited $\mathrm{Ca}^{+2}$ - or Al-induced root curvature, and the effects of captan and thiram on root curvature were additive. Serial concentration $(0,0.01,0.1,1,10$, or $100 \mathrm{mg} \cdot \mathrm{liter}^{-1}$ ) tests indicated that captan inhibited ${ }^{45} \mathrm{Ca}$ absorption the most at $100 \mathrm{mg} \cdot \mathrm{liter}^{-1}$, whereas thiram inhibited ${ }^{45} \mathrm{Ca}$ absorption the most at $0.01 \mathrm{mg} \cdot \mathrm{liter}^{-1}$. The effects of captan and thiram on ${ }^{45} \mathrm{Ca}$ absorption were statistically additive. Thiram seemed to influence $\mathrm{Ca}^{+2}$ uptake by affecting exofacial sulfhydryl groups (a mode of action similar to that of PCMBS). DTT reversed the inhibitory effect of thiram on ${ }^{45} \mathrm{Ca}$ absorption by $34 \%$ but did not reverse the effect of captan. A field test showed that acidic soil ( $(\mathrm{pH} 4.55$ ) reduced leaf number; leaf, stem, shoot, and whole-plant dry weights; and stem length of 15-day-old seedlings. Although there was no difference in root dry weights or root : shoot ratios of plants from pretreated and untreated seeds planted in soil at pH 6.26, planting commercially pretreated seeds in acidic soil produced plants with greater root dry weights and root : shoot dry weight ratios than those from untreated seeds. Seedlings showed a greater response to seed treatment in early growth stages. Captan and thiram may have influenced growth characteristics by inhibiting Al uptake of seedlings planted in acidic soil. To our knowledge, this is the first report on the influence of the fungicides captan and thiram on mineral ion uptake in roots. Chemical names used: $p$-Chloromercuribenzenesulfonic acid (PCMBS), dithiothreitol (DTT), $N$-trichloromethylthio-4-cyclohexene-1,2-dicarboximide(captan), tetramethylthiuram disulfide (thiram).
\end{abstract}

Captan and thiram are organic fungicides widely used as a seed coating or for foliar application. Their effects in controlling soiland seedborne fungi, protecting against many leaf-spot diseases, and thereby improving seed germination and seedling vigor have been reported by many authors (Durrant and Mash, 1991; Green et al., 1987; Nakagawa and Yamaguchi, 1989; Narasimhulu and Rao, 1989; Pardeshi et al., 1989). Although most protective fungicides presumably act by interfering with energy production and transport processes in the fungus (Green et al., 1987), some fungicides were reported to have detrimental effects on organisms other than the pathogens they were designed to control. For example, Hocking and Thomas (1979) reported that captan inhibits root formation in cuttings of ornamental plants. In rye (Secale cereale L. var. Snoopy) roots, captan combined with lindane (gamma isomer of benzene hexachloride) decreases cell elongation, increases cell size and root diameter, and produces high levels of polyploidy (Dille et al., 1986). These previous reports, however, did not identify the mode of action of either captan or thiram. In previous studies under disease-free conditions (unpublished data), we found a significant difference in seedling growth of untreated and pretreated (captan + thiram) watermelon seeds grown under low $\mathrm{pH}$, a result suggesting that these fungicides influence root function.

Received for publication 8 Feb. 1993. Accepted for publication 7 June 1993. The cost of publishing this paper was defrayed in part by the payment of page charges. Under postal regulations, this paper therefore must be hereby marked advertisement solely to indicate this fact.

${ }^{1}$ Graduate research assistant; Dept. of Horticulture. Present address: Dept. of Agronomy and Plant Genetics, Univ. of Minnesota, 1991 Buford Cir., St. Paul, MN 55108.

${ }^{2}$ Associate professor; Dept. of Horticulture. To whom reprint requests should be addressed.

${ }^{3}$ Professor; Dept. of Crop and Soil Sciences.
During commercial production in southern Georgia, watermelons are occasionally subjected to acidic soil $(\mathrm{pH}<5.0)$, which presents excess $\mathrm{H}^{+}, \mathrm{Mn}^{+2}$, and $\mathrm{Al}^{+3}$ and deficient $\mathrm{Ca}^{+2}$ and $\mathrm{Mg}^{+2}$ to the roots (Foy, 1984). Watermelon seeds generally are treated with captan and thiram by seed coating. If these fungicides influence root function, they could alter ion uptake in roots and, consequently, the growth characteristics of roots and shoots.

Root plasma membrane has many means of moving ions such as $\mathrm{H}^{+}$-ATPases, which function in $\mathrm{Ca}^{+2}$ influx (Serrano, 1984); $\mathrm{Ca}^{+2}$-ATPases, which function primarily in $\mathrm{Ca}^{+2}$ efflux (Hedrich and Schroeder, 1989); and cation channels (Hedrich and Schroeder, 1989; Hille, 1992). Plasma membrane-bound ATPases $\left(\mathrm{H}^{+}\right.$- or $\mathrm{Ca}^{+2}$-ATPase) have many requisite sulfhydryl ( $\mathrm{SH}$ ) groups, at least one of which is on the exofacial plasmalemma surface (Serrano, 1984). PCMBS is a membrane impermeant reagent that inactivates the exofacial SH groups of membrane-bound proteins. These proteins may be involved in moving substances through membranes in such diverse activities as sucrose accumulation in phloem sieve tubes (Giaquinta, 1976) to $\mathrm{Ca}, \mathrm{Mg}, \mathrm{K}, \mathrm{Zn}$, and $\mathrm{Cu}$ movement into roots (Wilkinson and Duncan, 1991; Wilkinson and Ohki, 1991). Applying $\mathrm{Ca}^{+2}$ and $\mathrm{Al}$ in agar unilaterally to the primary roots of sorghum [Sorghum bicolor (L.) Moench.] or maize (Zea mays L.) stopped elongation on the side contiguous with the agar, which induced root curvature (Ishikawas and Evans, 1992; Wilkinson and Duncan, 1992a, 1992b). Calcium and Al induce root curvature only when these ions are inside the plasma membrane (Wilkinson and Duncan, 1992a, 1992b). If $\mathrm{Ca}^{+2}$ and $\mathrm{Al}$ uptake is facilitated by the activity of $\mathrm{H}^{+}$-ATPase in watermelon seedling roots, PCMBS would inhibit the uptake of $\mathrm{Ca}^{+2}$ and $\mathrm{Al}$ applied unilaterally, thereby decreasing root curvature. DTT protects SH groups from inactivation by PCMBS (Giaquinta, 1976). If captan and thiram influence ion uptake by inactivating exofacial 
SH groups present in membrane-bound ATPases as does PCMBS (Wilkinson and Ohki, 1991; Wilkinson et al., 1992), the effect would be reversible by DTT.

Based on these hypotheses, we evaluated 'Starbrite' watermelon to determine 1) the individual and combined effects of captan and thiram on root response to $\mathrm{Ca}^{+2}$ and $\mathrm{Al}$ ions and 2) the influence of captan and thiram on growth characteristics of watermelon seedlings grown in acidic soil.

\section{Materials and Methods}

PCMBS and fungicide effects on root curvature. Commercially pretreated [4.38 g. $\mathrm{kg}^{-1}$ seed (captan $30 \%$ a.i. + thiram $30 \%$ a.i.)] and untreated 'Starbrite' watermelon seeds of the same seed lot were obtained. The seeds were planted in 'white quartz flintshot' sand and watered with deionized water in a growth chamber (28C, 14-h light, $\left.270 \mu \mathrm{mol} \cdot \mathrm{m}^{-2} \cdot \mathrm{s}^{-1}\right)$. After 4 days, the sand was washed and uniform seedlings were selected. The following treatments were applied to seedlings from untreated and pretreated seeds separately: a) $1 \%$ agar cubes $(1 \times 1 \times 1 \mathrm{~mm})$ (control); b) $1 \%$ agar containing $10 \mathrm{~mm} \mathrm{CaCl}_{2}$ (pH 5.4); c) $1 \%$ agar containing $10 \mathrm{~mm}$ $\mathrm{AlCl}_{3}(\mathrm{pH} \mathrm{3.4)}$; d) PCMBS + treatment b; and e) PCMBS + treatment $c$. For treatments $d$ and $e$, the roots were placed in PCMBS (1 mM) for $10 \mathrm{~min}$ before applying the agar cubes. Ten seedlings were selected for each replication, with eight replications per treatment. Seedlings were fastened with cellulose tape to $20 \times 20$-cm glass thin-layer chromatography (TLC) plates. Agar cubes were applied to one side of the root elongation zone. The plates were placed into paper-lined, water-saturated TLC tanks for $2 \mathrm{~h}$, and root curvature toward the agar cubes was measured with a protractor (Wilkinson and Duncan, 1992b). Curvature was measured in $5^{\circ}$ increments from $0^{\circ}$ to $90^{\circ}$.

Additive effect of captan and thiram on degree of curvature. Untreated watermelon seeds were divided into four groups: they were left untreated or dusted according to the commercial application rates with captan alone (140 $\mathrm{mg}$ a.i./100 seeds), thiram alone (130 mg a.i./100 seeds), and a combination of captan and thiram. The seeds were planted as previously described and uniform seedlings were selected. Agar cubes containing neither $\mathrm{CaCl}_{2}$ nor $\mathrm{AlCl}_{3}$ (control), $10 \mathrm{~mm} \mathrm{CaCl}_{2}$, or $10 \mathrm{~mm} \mathrm{AlCl}_{3}$ were fixed to one side of the roots following the same procedures as described above with eight replications of each treatment and 10 seedlings per replication. Root curvature around the agar cubes was measured.

Effect of captan or thiram concentration on ${ }^{45} \mathrm{Ca}$ absorption. Untreated watermelon seeds were planted in 'white quartz flintshot' sand in a growth chamber (same conditions as previously described) and watered with deionized water. After 4 days, uniform seedlings were harvested and exposed to the fungicides as described below, and ${ }^{45} \mathrm{Ca}$ absorption was determined by the methods of Wilkinson and Duncan (1992a, 1992b). Eight seedlings were fastened with cellulose tape onto a polyvinyl chloride holder. The roots were dipped in $1 \mathrm{M} \mathrm{NH}_{4} \mathrm{Cl}$ for 10 min to remove the mucigel layer, which absorbs $\mathrm{Al}$ and protects roots from $\mathrm{Al}$ injury (Horst et al., 1982). The roots were placed in deionized water for 2 min to wash off the extra $\mathrm{NH}_{4} \mathrm{Cl}$, then in ${ }^{45} \mathrm{Ca}$ solutions $(0.1 \mathrm{~mm}$ sodium acetate, $\mathrm{pH} 5.5)$ with six captan or thiram concentrations $(0,0.01$, $0.1,1,10$, or $100 \mathrm{mg} \cdot$ liter $^{-1}$ ) for $1 \mathrm{~h}$. To make the fungicide solutions, captan or thiram was dissolved in chloroform and placed into the treatment containers; the chloroform was then evaporated and buffer solution was added. After treatment, the roots were placed into $5 \mathrm{mM} \mathrm{CaCl}_{2}$ solution for $10 \mathrm{~min}$ to wash off the surface ${ }^{45} \mathrm{Ca}$. All eight roots tips (the lower $1 \mathrm{~cm}$ ) were cut off and put into glass scintillation vials. These eight roots made one replication.
There were five replications per fungicide concentration. After adding $10 \mathrm{ml}$ scintillation fluid (Scintiverse BD; Fisher Scientific, Pittsburgh) to the vials, ${ }^{45} \mathrm{Ca}$ was quantified via liquid scintillation spectrometry. The amount of $\mathrm{Ca}^{+2}$ absorbed was calculated in disintegrations per min (dpm) based on the total ${ }^{45} \mathrm{Ca}$ amount.

Additive effect of captan and thiram on ${ }^{45} \mathrm{Ca}$ absorption. From the results of the captan and thiram concentration tests, we chose the concentration most effective in reducing ${ }^{45} \mathrm{Ca}$ absorption. Four treatments were selected to test the additive effect of captan and thiram on ${ }^{45} \mathrm{Ca}$ absorption: 1) control, 2) captan (100 mg.liter $\left.\left.{ }^{-1}\right), 3\right)$ thiram $\left(0.1 \mathrm{mg} \cdot \mathrm{liter}^{-1}\right)$, and 4) captan + thiram at the selected individual concentrations. The experiment used the same ${ }^{45} \mathrm{Ca}$ absorption protocol as in the captan and thiram concentration tests. There were five replications per treatment and eight roots per replication.

DTT reversal test. Using the selected concentrations of captan and thiram, we tested for reversal of fungicide effects by adding DTT to the ${ }^{45} \mathrm{Ca}+$ fungicide solution. The treatments were as follows: 1) control, 2) DTT, 3) captan or thiram, and 4) DTT + either captan or thiram. To ensure excess DTT, the concentration used was 10 times that of the fungicide. The same protocol for measuring ${ }^{45} \mathrm{Ca}$ absorption was used as in the fungicide concentration tests. There were five replications per treatment with eight roots per replication.

Field test. Untreated and commercially pretreated 'Starbrite' watermelon seeds were sown at the Georgia Experiment Station near Griffin, Ga., on 21 July 1991 in normal (water $\mathrm{pH}=6.26$ ) and acidic (water $\mathrm{pH}=4.55$ ) plots of Pocolet sandy clay (clayey, kaolinitic, thermic Typic Kanhapludult), in which exchangeable Al level ranges from 110 to $275 \mu \mathrm{g} \cdot \mathrm{g}^{-1}$ and organic matter content is $<15 \mathrm{~g} \cdot \mathrm{kg}^{-1}$ (Miller et al., 1992). Each seed treatment and soil pH combination was replicated six times in a split-plot design. After 15 days, seedlings were harvested and leaf number; leaf, stem, root, shoot, and whole-plant dry weight; and stem length were measured. Roots were recovered by transporting a $12.7-\mathrm{cm}$-diameter root ball of each seedling to the laboratory and the soil was washed off in a 40-mesh sieve. Root : shoot dry weight ratios were calculated. For each treatment, each replication was the mean of six plants. The test was repeated in the same plots on 8 Sept. 1992, but only shoot data were collected.

Statistical analyses. Laboratory experiments were designed as randomized complete blocks and the field experiment was a splitplot design. Data were subjected to SAS's general linear models procedure (Littell et al., 1991). Mean separation of treatment effects on seedling growth in the field test or on root curvature or ${ }^{45} \mathrm{Ca}$ absorption was by least significant difference (LSD) at $P \leq$ 0.05 . Regression analysis of log-transformed concentrations modeled the effect of captan on ${ }^{45} \mathrm{Ca}$ absorption. Since regression models were nonsignificant, orthogonal contrasts were used to model the effect of thiram concentration on ${ }^{45} \mathrm{Ca}$ absorption. Statistical analyses for additive effects were conducted using the herbicide interaction method developed by Flint et al. (1988).

\section{Results and Discussion}

PCMBS and fungicide effects on root curvature. Although unilateral application of $\mathrm{Ca}^{+2}$ and $\mathrm{Al}$ in agar induced curvature in roots from untreated and pretreated seeds, roots from untreated seeds were much more responsive to both ions relative to the respective controls (Fig. 1). For the roots from untreated seeds (Fig. 1A), the degree of curvature caused by $\mathrm{Al}$ was greater than that by $\mathrm{Ca}^{+2}$. Using PCMBS before applying $\mathrm{Ca}^{+2}$ or $\mathrm{Al}$ inhibited root curvature. The percent inhibition of degree of curvature by 


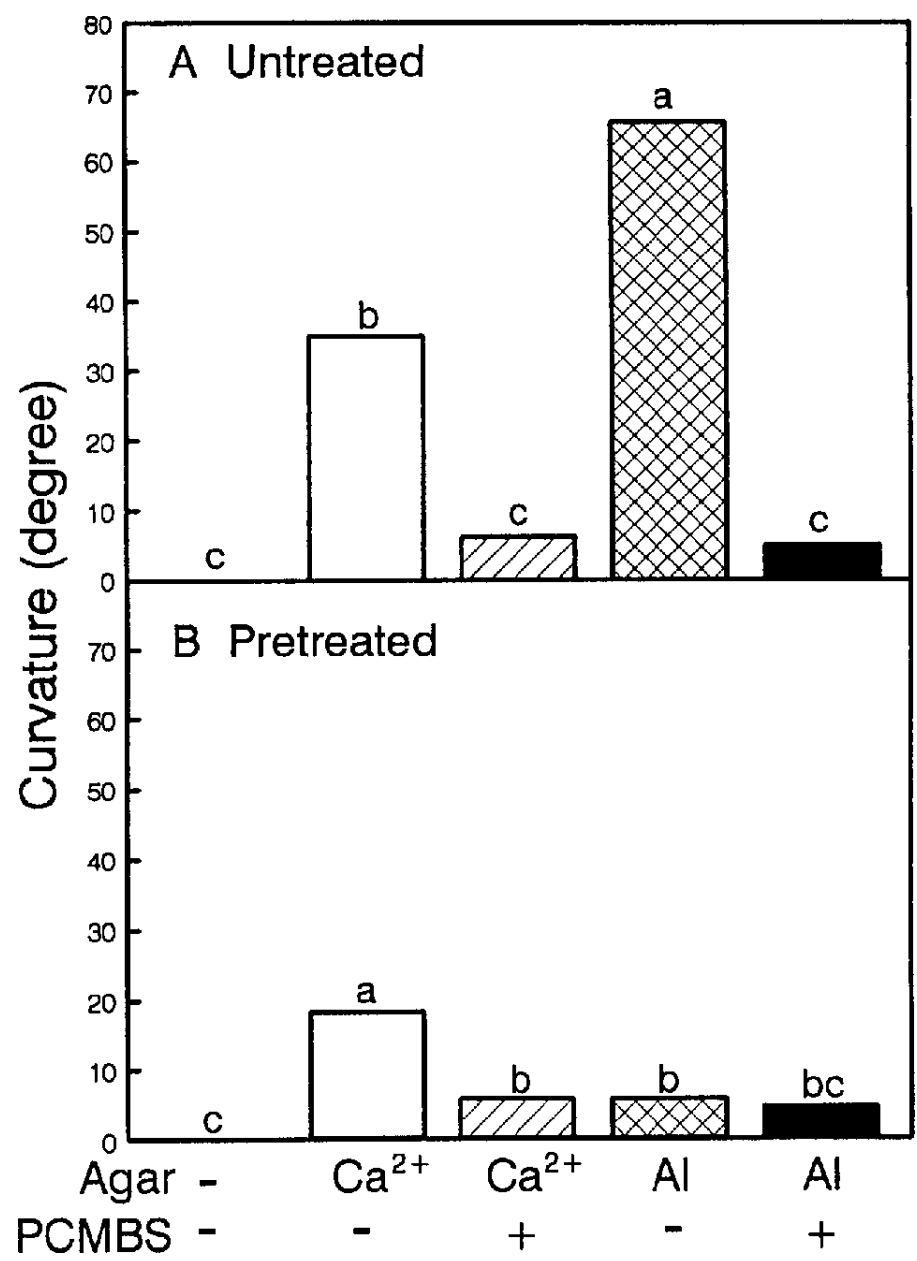

Fig. 1. Degree of root curvature of watermelon seedlings as influenced by seed treatment and PCMBS after applying agar $\pm \mathrm{Ca}^{+2}$ or Al. (A) Untreated seeds. (B) Commercial fungicide-pretreated seeds. Bars with the same letter within seed treatment are not significantly different at $P \leq 0.05$ by LSD.
PCMBS in roots from untreated seeds was $82 \%$ for $\mathrm{Ca}^{+2}$-induced curvature and $92 \%$ for Al-induced curvature. In plants, transport of ions across the plasma membranes is dominated by the activities of $\mathrm{H}^{+}$-ATPases, which generate a proton electrochemical potential gradient and provide the driving force for ion transport via ion channels, and $\mathrm{Ca}^{+2}$-ATPases, which primarily function in $\mathrm{Ca}^{+2}$ efflux (Hedrich and Schroeder, 1989; Wimmers et al., 1990). Calcium and $\mathrm{Al}$ induce root curvature when they are inside the plasma membrane (Wilkinson and Duncan, 1992a, 1992b). Channel blockers inhibit root curvature by inhibiting $\mathrm{Ca}^{+2}$ and $\mathrm{Al}$ uptake (Wilkinson and Duncan, 1992a, 1992b). PCMBS has been reported to inhibit $\mathrm{H}^{+}$-ATPases by inactivating $\mathrm{SH}$ groups (Vara and Serrano, 1982), and exofacial SH groups have not been postulated as components in cation channels (Hedrich and Schroeder, 1989; Hille, 1992; Serrano, 1984). Therefore, the reduction in curvature was presumably due to decreased $\mathrm{Ca}^{+2}$ or $\mathrm{Al}$ uptake resulting from the inactivition of $\mathrm{H}^{+}$-ATPases by PCMBS. Calcium- and Al-induced curvature in roots from pretreated seeds was severely limited, presumably by the fungicide pretreatment (Fig. 1B). PCMBS further inhibited the root curvature induced by $\mathrm{Ca}^{+2}$ but had no additional effect on Al-induced curvature. The fungicides may act in such a mode that limits ion uptake, especially as observed with $\mathrm{Al}$, so the roots exhibit less response to PCMBS in the presence of fungicides. Hence, the mode of action of captan and thiram on ion absorption may be similar to that of PCMBS.

Additive effect of captan and thiram on root curvature. When used alone, captan greatly decreased $\mathrm{Al}$ - but not $\mathrm{Ca}^{+2}$-induced root curvature (Fig. $2 \mathrm{~A}$ and B). Thiram inhibited Al- and $\mathrm{Ca}^{+2}$-induced root curvature. Applying captan and thiram simultaneously decreased Al- and $\mathrm{Ca}^{+2}$-induced root curvature. When commercially prepared, watermelon seeds are treated with a combination of captan and thiram. This combination tends to enhance the inhibition of root curvature compared to either fungicide alone (Fig. 2 A and B).

In a statistical model developed for analyzing herbicide interactions, Flint et al. (1988) used a general linear model (SAS GLM) analysis of the effect of the chemicals, applied individually and

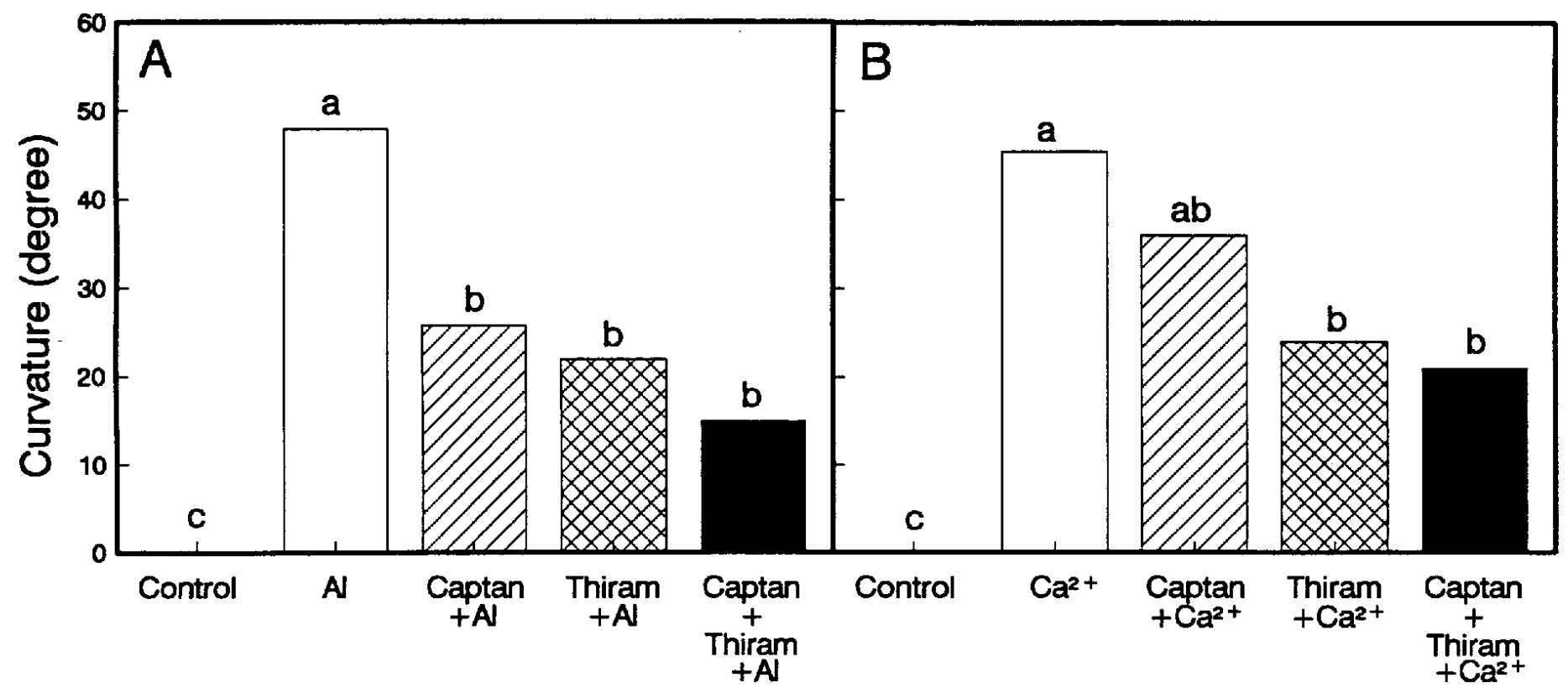

Fig. 2. The effect of captan or thiram on degree of root curvature after applying agar $\pm \mathrm{Al}(\mathbf{A})$ or $\mathrm{Ca}^{+2}(\mathbf{B})$. Bars with the same letter within ion treatment are not significantly different at $P \leq 0.05$ by LSD. 
combined, on test parameters such as plant dry weight. A significant $(P \leq 0.05) t$ value for the effect of the combined chemicals indicates the presence of an interaction, and the sign of the test parameter estimate for the combined chemicals determines whether the interaction is synergistic or antagonistic. If the $t$ value for the combined chemicals is not significant, the model defines the effect as additive. In our case, the significance of the combined effect of captan and thiram on root curvature was $P=0.34$ for $\mathrm{Ca}^{+2}$ and $P=$ 0.76 for $\mathrm{Al}$. In the absence of significant interactive effects, we conclude that the effects of captan and thiram on root curvature were additive.

Captan and thiram concentration tests. Calcium-45 was used to determine the effects of fungicide concentration on $\mathrm{Ca}^{+2}$ absorption. The captan concentration effect had a significant $(P \leq 0.05)$ linear trend from 0 to $100 \mathrm{mg} \cdot$ liter $^{-1}$ (Table 1$)$. In the experimental concentration range, captan inhibited ${ }^{45} \mathrm{Ca}$ absorption the most at $100 \mathrm{mg} \cdot \mathrm{liter}^{-1}$. Since $100 \mathrm{mg} \cdot \mathrm{liter}^{-1}$ was the upper limit of the selected concentration series, the effect of captan at higher concentrations needs further experimental work.

Thiram induced the strongest inhibition (36\%) of $\mathrm{Ca}^{+2}$ absorption at concentrations as low as $0.1 \mathrm{mg} \cdot \operatorname{liter}^{-1}$ (Table 2). Calcium45 uptake in response to thiram concentration did not yield a significant regression. However, analysis by orthogonal contrasts revealed that the concentrations that we tested below $0.1 \mathrm{mg} \cdot$ liter $^{-}$ ${ }^{1}$ had no effect on ${ }^{45} \mathrm{Ca}$ uptake and those $\geq 0.1 \mathrm{mg} \cdot \mathrm{liter}^{-1}$ caused an equivalent reduction. Within the experimental concentration ranges,

Table 1. Average ${ }^{45} \mathrm{Ca}$ absorption and uptake percentage as influenced by captan concentration $(n=5)$.

\begin{tabular}{lcc}
\hline \hline $\begin{array}{l}\text { Captan } \\
\text { concn } \\
\left(\mathrm{mg} \cdot \text { liter }^{-1}\right)\end{array}$ & $\begin{array}{c}\text { Average }{ }^{45} \mathrm{Ca} \\
\text { absorption } \\
(\mathrm{dpm} \times 1000)\end{array}$ & $\begin{array}{c}{ }^{45} \mathrm{Ca} \\
\text { uptake } \\
(\%)\end{array}$ \\
\hline 0.00 & 8.50 & 100.0 \\
0.01 & 8.61 & 101.3 \\
0.10 & 7.87 & 92.6 \\
1.00 & 8.35 & 98.3 \\
10.00 & 5.66 & 66.6 \\
100.00 & 4.82 & 56.8 \\
Significance & $\mathrm{L}^{\mathrm{z}}$ & $\mathrm{L}^{*}$ \\
\hline
\end{tabular}

${ }^{\mathrm{z}}$ Significance of linear $(\mathrm{L})$ trends of log-transformed concentration $(0.01$ to $100 \mathrm{mg} \cdot l$ liter $^{-1}$ ) vs. ${ }^{45} \mathrm{Ca}$ absorption or uptake percentage.

${ }^{*}$ Significant $\mathrm{F}$ test at $P \leq 0.05$.

Table 2. Average ${ }^{45} \mathrm{Ca}$ absorption and uptake percentage as influenced by thiram concentration $(n=5)$.

\begin{tabular}{|c|c|c|}
\hline $\begin{array}{l}\text { Thiram } \\
\text { concn } \\
\left(\mathrm{mg} \cdot \text { liter }^{-1}\right)\end{array}$ & $\begin{array}{c}\text { Average }{ }^{45} \mathrm{Ca} \\
\text { absorption } \\
(\mathrm{dpm} \times 1000)\end{array}$ & $\begin{array}{c}{ }^{45} \mathrm{Ca} \\
\text { uptake } \\
(\%)\end{array}$ \\
\hline \multicolumn{3}{|l|}{ Treatment (T) } \\
\hline $0.00\left(\mathrm{~T}_{1}\right)$ & 32.41 & 100.0 \\
\hline $0.01\left(\mathrm{~T}_{2}\right)$ & 34.15 & 105.4 \\
\hline $0.10\left(\mathrm{~T}_{3}\right)$ & 20.75 & 64.0 \\
\hline $1.00\left(\mathrm{~T}_{4}^{3}\right)$ & 22.47 & 69.3 \\
\hline $10.00\left(\mathrm{~T}_{5}\right)$ & 25.06 & 77.3 \\
\hline $100.00\left(\mathrm{~T}_{6}\right)$ & 24.25 & 74.8 \\
\hline \multicolumn{3}{|l|}{ Orthogonal contrast } \\
\hline$\left(\mathrm{T}_{1}+\mathrm{T}_{2}\right)$ vs. $\left(\mathrm{T}_{3}+\mathrm{T}_{4}+\mathrm{T}_{5}+\mathrm{T}_{6}\right)$ & $* * *$ & $* * *$ \\
\hline $\mathrm{T}_{1}$ vs. $\mathrm{T}_{2}$ & NS & NS \\
\hline $\mathrm{T}_{2}$ vs. $\mathrm{T}_{3}$ & $* * *$ & $* * *$ \\
\hline $\mathrm{T}_{3}$ vs. $\mathrm{T}_{5}$ & NS & NS \\
\hline
\end{tabular}

Ns,**** Nonsignificant or significant at $P \leq 0.001$. concentrations as low as $0.1 \mathrm{mg} \cdot \mathrm{liter}^{-1}$ cause the inhibitory effect of thiram. There have been no previous reports describing an inhibitory effect of captan or thiram on ion absorption.

Additive effect of captan and thiram on ${ }^{45} \mathrm{Ca}$ absorption. To further test the additive effects of captan and thiram, the ${ }^{45} \mathrm{Ca}$ absorption test was conducted with selected concentrations (cap-

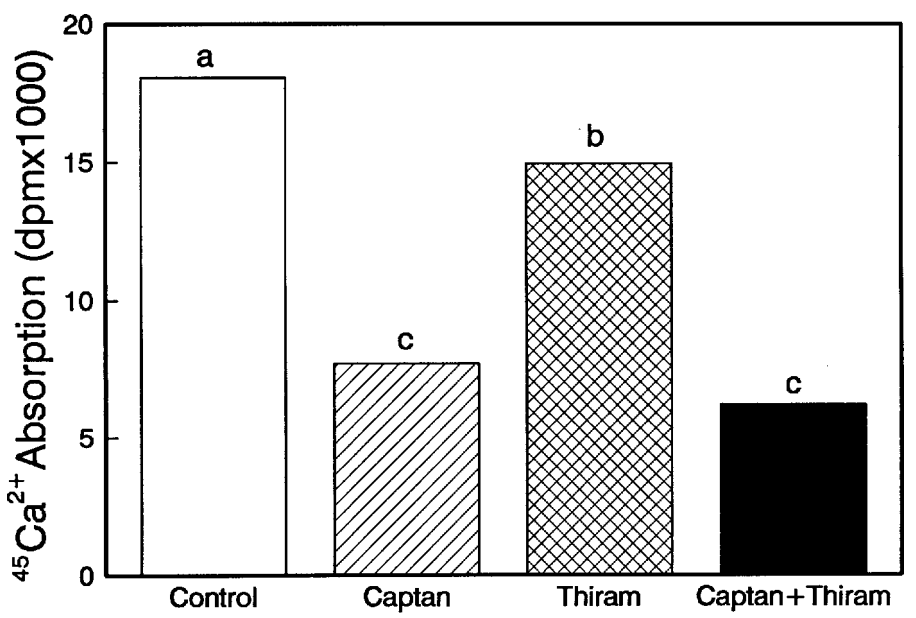

Fig. 3. The effect of captan at $100 \mathrm{mg} \cdot$ liter $^{-1}$ or thiram at $0.1 \mathrm{mg} \cdot$ liter $^{-1}$ on ${ }^{45} \mathrm{Ca}$ absorption by the roots of watermelon seedlings. Bars with the same letter are not significantly different at $P \leq 0.05$ by LSD.

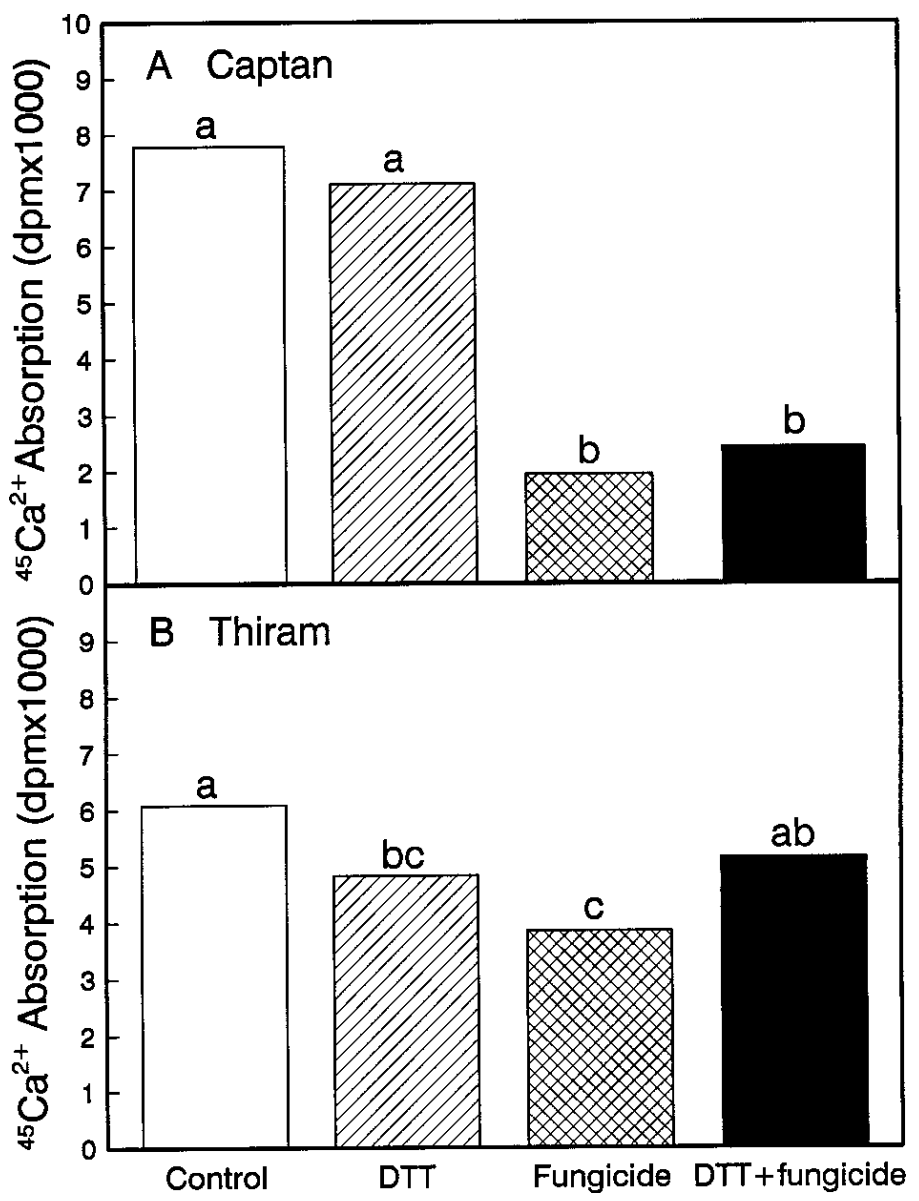

Fig. 4. Test of DTT's reversal of the effect of fungicides on ${ }^{45} \mathrm{Ca}$ absorption by watermelon roots. (A) Captan at $100 \mathrm{mg} \cdot \mathrm{liter}^{-1}$. (B) Thiram at 0.1 $\mathrm{mg} \cdot$ liter $^{-1}$. Bars with the same letter within fungicides are not significantly different at $P \leq 0.05$ by LSD. 
tan, $100 \mathrm{mg} \cdot$ liter $^{-1}$; thiram, $0.1 \mathrm{mg} \cdot$ liter $^{-1}$ ) (Fig. 3). Based on the results of the LSD analysis, captan and thiram inhibited ${ }^{45} \mathrm{Ca}$ absorption when used alone, although captan had a stronger effect on ${ }^{45} \mathrm{Ca}$ uptake than thiram. However, the same statistical model (Flint et al., 1988) as previously stated for root curvature analysis was used to analyze the interactive effects of captan and thiram on $\mathrm{Ca}^{+2}$ absorption. The results showed that the effects of captan and thiram on ${ }^{45} \mathrm{Ca}$ absorption were additive $(P=0.77)$. In our previous test using commercial fungicide rates, there was no difference in the effect of captan and thiram on root curvature (Fig. 2). This may be because the concentration used to treat the seeds was not in the most effective range for inhibiting $\mathrm{Ca}^{+2}$ absorption. In this previous test, commercially pretreated seeds were planted in sand where the fungicides would be gradually flushed away during watering. Roots may have been exposed to the fungicides only at the early germination stage, and thus were affected less. In the ${ }^{45} \mathrm{Ca}$ absorption test, roots were dipped in fungicide solutions and exposed to a high ambient concentration.

DTT reversal test. DTT reverses the inactivating effect of PCMBS on SH groups. If captan and thiram act in a mode similar to PCMBS, their effects should also be reversed by DTT. The inhibitory effects of captan and thiram on ${ }^{45} \mathrm{Ca}$ absorption (Fig. 4) were consistent with the results shown in Fig. 3. Although captan greatly inhibited ${ }^{45} \mathrm{Ca}$ absorption, its effect was not reversed by adding DTT (Fig 4A). In contrast, DTT reversed the inhibitory effect of thiram on ${ }^{45} \mathrm{Ca}$ absorption by $34 \%$ relative to DTT alone (Fig. 4B). Possibly, the inactivation of SH groups by captan is stronger and more difficult to reverse, or is irreversible. This result suggests that captan and thiram act differently in reducing $\mathrm{Ca}^{+2}$ absorption. Thiram seemed to act in a mode of action similar to that of PCMBS. In addition, DTT alone reduced ${ }^{45} \mathrm{Ca}$ absorption in the thiram test (Fig. 4A), but not in the captan test (Fig. 4B). Wilkinson and Ohki (1991) observed the phenomenon of DTT enhancement of ${ }^{45} \mathrm{Ca}$ absorption in wheat. The difference in these results may be due to the use of different DTT concentrations or plant species.

Field test. In 1991, acidic soil significantly decreased all shoot growth characteristics measured, while the effects of seed treatment on shoot growth were not significant except for stem length, which was greater for seedlings from fungicide-pretreated seeds (Table 3). Shoot dry weight was reduced $32 \%$ in acidic soil compared to normal soil. Root dry weights and root : shoot dry weight ratios exhibited significant interactions between soil $\mathrm{pH}$ and seed treatment (Table 4). When planted in acidic soil, pretreated seeds produced plants with greater root dry weights, but planting pretreated seeds in normal soil did not affect root dry weights. Although no direct data show the effect of fungicides on Al uptake, Al-induced root curvature and the negative response of curvature to PCMBS and fungicides as described in the laboratory tests suggest that $\mathrm{Al}$ absorption is reduced by treating seeds with fungicides. When planted in an acidic soil that contains excess $\mathrm{Al}$, the seedlings from pretreated seeds (captan + thiram) had better root growth characteristics. The inhibition of $\mathrm{Al}$ absorption by captan and thiram as suggested by laboratory test results would reduce $\mathrm{Al}$ toxicity to roots in acidic soil. This action would explain the lack of difference in root dry weights between the two soil pHs when using pretreated seeds and the reduced root dry weights of plants from untreated seeds in acidic soil. Root : shoot dry weight ratios also increased in pretreated seeds planted in the acidic soil, but not in normal soil. However, in contrast to root dry weights, plants from untreated seeds did not differ in root : shoot ratios, but plants from pretreated seeds had greater root : shoot ratios in the low-pH soil. This was due to the marked decrease in shoot dry weight in the acidic soil without a corresponding decrease in root dry weight. Generally, Al toxicity to the roots in acidic soil was reduced by treating seeds with fungicides. This treatment resulted in good root growth and a high root : shoot ratio. The high root : shoot ratio was gained by decreased shoot dry weight. Shoot response to seed treatment was further tested by repeating the test

Table 3. Growth characteristics of 15-day-old 'Starbrite' watermelon seedlings as affected by soil pH (pH 6.26 and 4.55) and seed fungicide treatment in 1991 and $1992(\mathrm{n}=36)$.

\begin{tabular}{|c|c|c|c|c|c|c|}
\hline \multirow[b]{2}{*}{ Treatment } & \multirow{2}{*}{$\begin{array}{c}\text { No. } \\
\text { of } \\
\text { leaves }\end{array}$} & \multicolumn{4}{|c|}{ Dry wt (mg) } & \multirow{2}{*}{$\begin{array}{l}\text { Stem } \\
\text { length } \\
(\mathrm{cm})\end{array}$} \\
\hline & & Leaf & Stem & Shoot & $\begin{array}{l}\text { Whole } \\
\text { plant }\end{array}$ & \\
\hline \multicolumn{7}{|c|}{1991} \\
\hline \multicolumn{7}{|l|}{ Soil pH } \\
\hline 6.26 & 3.5 & 196 & 42 & 238 & 248 & 9.3 \\
\hline 4.55 & 3.1 & 133 & 28 & 161 & 170 & 8.3 \\
\hline Significance & $*$ & $* * *$ & $* *$ & $* * *$ & $* * *$ & $*$ \\
\hline \multicolumn{7}{|l|}{ Seed treatment } \\
\hline Untreated & 3.2 & 159 & 35 & 194 & 202 & 8.4 \\
\hline Pretreated & 3.4 & 170 & 35 & 206 & 215 & 9.2 \\
\hline Significance & NS & NS & NS & NS & NS & $* * *$ \\
\hline Soil $\times$ seed & NS & $\begin{array}{l}\text { NS } \\
1992\end{array}$ & NS & NS & NS & NS \\
\hline \multicolumn{7}{|l|}{ Soil pH } \\
\hline 6.26 & 2.3 & 91 & 42 & 133 & & 6.4 \\
\hline 4.55 & 1.7 & 61 & 26 & 87 & & 5.2 \\
\hline Significance & $*$ & $*$ & $* *$ & $*$ & & $*$ \\
\hline \multicolumn{7}{|l|}{ Seed treatment } \\
\hline Untreated & 1.8 & 66 & 32 & 99 & & 5.3 \\
\hline Pretreated & 2.2 & 85 & 36 & 121 & & 6.3 \\
\hline Significance & $* * *$ & $* *$ & NS & $* *$ & & $* * *$ \\
\hline Soil $\times$ seed & NS & NS & NS & NS & & NS \\
\hline
\end{tabular}

NS,*,**,**** Nonsignificant or significant F test at $P \leq 0.05,0.01$, or 0.001 , respectively. 
Table 4. The effects of seed fungicide treatment and soil $\mathrm{pH}(\mathrm{pH} 6.26$ and 4.55) on root dry weight and root : shoot dry weight ratio of 15-day-old 'Starbrite' watermelon in $1991(\mathrm{n}=36)$.

\begin{tabular}{|c|c|c|c|c|c|c|}
\hline \multirow[b]{3}{*}{ Treatment } & \multicolumn{3}{|c|}{ Root dry wt (mg) } & \multicolumn{3}{|c|}{ Root : shoot ratio } \\
\hline & \multicolumn{3}{|c|}{ Soil pH } & \multicolumn{3}{|c|}{ Soil pH } \\
\hline & 6.26 & 4.55 & Significance & 6.26 & 4.55 & Significance \\
\hline Untreated & 10.12 & 7.26 & $* * *$ & 0.045 & 0.049 & NS \\
\hline Pretreated & 9.96 & 9.79 & NS & 0.042 & 0.059 & $* * *$ \\
\hline Significance & NS & $* * *$ & & NS & $* *$ & \\
\hline Soil $\times$ seed & \multicolumn{3}{|c|}{$* * *$} & \multicolumn{2}{|c|}{$* *$} & \\
\hline
\end{tabular}

NS, ${ }^{* *},{ }^{* * *}$ Nonsignificant or significant $\mathrm{F}$ test at $P \leq 0.01$ or 0.001 , respectively.

the following year (1992, Table 3). In acidic soil, leaf number, leaf and stem dry weight, and stem length decreased as discussed above. However, pretreated seeds produced greater leaf and shoot dry weights under both soil conditions than untreated seeds in the 1992 test. Seedlings from the 1992 test were smaller and less developed than those from the 1991 test (due to seasonal or environmental factors), a result suggesting that fungicide treatments may be more effective at the early growth stage of the seedlings. In addition, during the experimental periods, no diseases symptoms were observed. Therefore, pathogens were not a factor affecting plant growth in this experiment.

In this report we have shown, by using ${ }^{45} \mathrm{Ca}$, that $\mathrm{Ca}^{+2}$ absorption in watermelon seedling roots is inhibited by PCMBS and the fungicides captan and thiram. The effects of captan and thiram are additive and concentration dependent. Thiram seemed to inhibit $\mathrm{Ca}^{+2}$ absorption in a mode similar to that of PCMBS. It is most likely that $\mathrm{H}^{+}$-ATPase is affected, reducing the electrochemical potential gradient produced, which, in turn, reduces $\mathrm{Ca}^{+2}$ absorption and probably that of $\mathrm{Al}$ as well. Calcium-ATPase may also be affected, thereby reducing $\mathrm{Ca}^{+2}$ efflux (Serrano, 1984). Since the effect of captan on $\mathrm{Ca}^{+2}$ absorption is not reversible, captan's mode of action on $\mathrm{Ca}^{+2}$ uptake inhibition is undetermined. Possibly, captan and thiram act independently in their individual modes of action, but additional evidence is still needed.

Aluminum toxicity is a major factor limiting plant growth in acidic soil (Foy, 1984). Understanding the physiological and biochemical basis of Al toxicity and its movement across the plasma membrane is required. Kinetic analysis has been used to estimate the rate of movement of $\mathrm{Al}$ across the plasma membrane (Schaedle et al., 1986; Wagatsuma, 1983; Zhang and Taylor, 1990). However, we can not explain how Al moves into plant tissue as we did for $\mathrm{Ca}^{+2}$ because of the lack of a suitable $\mathrm{Al}$ isotope. In the 1991 field test, seed treatment resulted in an increased root dry weight in acidic soil, but no difference was observed between normal and acidic soils. Therefore, fungicides seem to have partially alleviated the $\mathrm{Al}$ toxicity to the roots. We presume that this reduced $\mathrm{Al}$ toxicity is due to reduced $\mathrm{Al}$ absorption, which may be explained as the inactivity of transport proteins, as in the case of $\mathrm{Ca}^{+2}$. Although $\mathrm{Ca}^{+2}$ (deficient in acidic soil) uptake is also inhibited by the fungicides, $\mathrm{Al}$ saturation is the dominant problem in acidic soil. Therefore, the benefits of $\mathrm{Al}$ uptake inhibition may override the negative effect of reduced $\mathrm{Ca}^{+2}$ uptake, resulting in a net improvement in plant growth.

\section{Literature cited}

Dille, J.E., E.N. King, and M. Bright. 1986. Morphological and cytogenetic effects of isotox 25 seed treater (F) (lindane and captan) on roots and chromosomes of rye (Secale cereale L.). Cytologia 51:489-492.

Durrant, M.J. and S.J. Mash. 1991. Sugar beet seed steep treatments to improve germination under cold, wet conditions. Plant Growth Regulat. 10(1):45-55.
Flint, J.L., P.L. Cornelius, and M. Barrett. 1988. Analyzing herbicide interactions: A statistical treatment of Colby's method. Weed Technol. 2:304-309.

Foy, C.D. 1984. Physiological effects of hydrogen, aluminum, and manganese toxicities in acid soil, p. 57-97. In: F. Adams (ed.). Soil acidity and liming. 2nd ed. Amer. Soc. Agron., Madison, Wis. Monogr. 12.

Giaquinta, R.T. 1976. Evidence for phloem loading from the apoplast: Chemical modification of membrane sulfhydryl groups. Plant Physiol. 57:872-875.

Green, M.B., G.S. Hartley, and T.F. West. 1987. Chemicals for crop improvement and pest management. 3rd ed. Pergamon Press, Oxford, New York.

Hedrich, R. and J.I. Schroeder. 1989. The physiology of ion channels and electrogenic pumps on higher plants. Annu. Rev. Plant Physiol. 40:539560 .

Hille, B. 1992. Ionic channels of excitable membranes. 2nd ed. Sinauer Associates, Sunderland, Mass.

Hocking, P.J. and M.B. Thomas. 1979. Effect of IBA in combination with thiram, captan and benomyl on the rooting of four ornamental species. N.Z. J. Expt. Agr. 7(3):263-270.

Horst, W.J., A. Wagener, and H. Marschner. 1982. Mucilage protect root meristems from aluminum injury. Z. Pflanzenphysiol. 105:435-444.

Ishikawas H. and M.L. Evans. 1992. Induction of curvature in maize roots by calcium or by thigmostimulation. Plant Physiol. 100:762-768.

Littell, R.C., F.J. Freund, and P.C. Spector. 1991. SAS system for linear models. SAS Institute, Cary, N.C.

Miller D.R., R.M. Waskom, and R.R. Duncan. 1992. Acid soil stress tolerance in tissue culture-derived sorghum lines. Crop Sci. 32:324327.

Nakagawa, A. and T. Yamaguchi. 1989. Seed treatment for control of seed-borne Fusarium roseum on wheat. Jpn. Agr. Res. Quarterly 23(2):94-99.

Narasimhulu, T. and P.K. Rao. 1989. Effect of seed treatment with insecticides and fungicides on the germination of peanut seed. Seed Res. 17(2):159-163.

Pardeshi, V.F., V.G. Reddy, and P.K. Nalwandikar. 1989. Effects of different fungicides on seedling vigor and seed viability in soybean. J. Maharashtra Agr. Univ. 14(1):33-36.

Schaedle, M., F.C. Thornton, and D.J. Raynal. 1986. Non-metabolic binding of aluminum to roots of loblolly pine and honeylocust. J. Plant Nutr. 9:1227-1238.

Serrano, R. 1984. Plasma membrane ATPase of fungi and plants as a novel type of proton pump. Current Topics in Cellular Regulat. 23:87-126.

Vara, F. and R. Serrano. 1982. Partial purification and properties of the proton-translocation ATPase of plant plasma membranes. J. Biol. Chem. 257:12826-12830.

Wagatsuma, T. 1983. Effect of non-metabolic conditions on the uptake of aluminum by plant roots. Soil Sci. Plant Nutr. 29:323-333.

Wilkinson, R.E. and R.R. Duncan. 1991. Sorghum cultivar variation in $\mathrm{Ca}^{2+}$ and aluminum influence on root curvature. J. Plant Nutr. 14:741749.

Wilkinson, R.E. and R.R. Duncan. 1992a. Verapamil influence on calcium and aluminum absorption by roots of three sorghum cultivars. J. Plant Nutr. 15(1):15-21.

Wilkinson, R.E and R.R. Duncan. 1992b. Diltiazem influence on calcium 
and aluminum absorption by roots of three sorghum cultivars. J. Plant Nutr. 15(2):211-218.

Wilkinson, R.E., R.R. Duncan, C. Berry, and I. Deram. 1992. Nifedipine influence on calcium and aluminum absorption in roots of three sorghum cultivars. J. Plant Nutr. 15:191-198.

Wilkinson, R.E. and K. Ohki. 1991. Effect of PCMBS and EPTC on mineral nutrient uptake and translocation in wheat. J. Plant Nutr.
14(1):93-108.

Wimmers, L.E., N.N. Ewing, D.J. Meyer, and A.B. Bennett. 1990. Calcium in plant growth and development, p. 36-44. In: R.T. Leonard and P.K. Hepler (eds.). Amer. Soc. Plant Physiol. Symp. Ser. vol. 4. Amer. Soc. Plant Physiol., Rockville, Md.

Zhang, G. and G.J. Taylor. 1990. Kinetics of aluminum uptake in Triticum aestivum L. Plant Physiol. 94:577-584. 